\title{
The effects of cow genetic group on the density of raw whole milk
}

\author{
P. Parmar ${ }^{1,3}$, N. Lopez-Villalobos ${ }^{2}$, J.T. Tobin ${ }^{3}$, E. Murphy ${ }^{3}$, F. Buckley ${ }^{4}$, A. McDonagh ${ }^{5}$, J.A. O'Mahony ${ }^{6}$, S.V. Crowley ${ }^{6}$, \\ A.L. Kelly ${ }^{6}$, L. Shalloo ${ }^{1 \dagger}$ \\ ${ }^{1}$ Livestock Systems Department, Teagasc Food Research Centre, Moorepark, Fermoy, Co. Cork, P61 C996, Ireland \\ ${ }^{2}$ School of Agriculture and Environment, Massey University, Palmerston North, 4442, New Zealand \\ ${ }^{3}$ Food Chemistry and Technology Department, Teagasc Food Research Centre, Moorepark, Fermoy, Co. Cork, P61 C996, Ireland \\ ${ }^{4}$ Animal and Bioscience Department, Teagasc Food Research Centre, Moorepark, Fermoy, Co. Cork, P61 C996, Ireland \\ ${ }^{5}$ Grassland Science Department, Teagasc Food Research Centre, Moorepark, Fermoy, Co. Cork, P61 C996, Ireland \\ ${ }^{6}$ School of Food and Nutritional Sciences, University College Cork, Cork, T12 K8AF, Ireland
}

Abstract

The density of milk is dependent upon various factors including temperature, processing conditions, and animal breed. This study evaluated the effect of different cow genetic groups, Jersey, elite Holstein Friesians (EHF), and national average Holstein Friesians (NAHF) on the compositional and physicochemical properties of milk. Approximately 1,040 representative (morning and evening) milk samples ( 115 per month during 9 mo) were collected once every 2 wk. Milk composition was determined with a Bentley Dairyspec instrument. Data were analysed with a mixed linear model that included the fixed effects of sampling month, genetic group, interaction between month and genetic group and the random effects of cow to account for repeated measures on the same animal. Milk density was determined using three different analytical approaches a portable and a standard desktop density meter and $100 \mathrm{~cm}^{3}$ calibrated glass pycnometers. Milk density was analysed with the same mixed model as for milk composition but including the analytical method as a fixed effect. Jersey cows had the greatest mean for fat content $(5.69 \pm 0.13 \%)$, followed by EHF $(4.81 \pm 0.16 \%)$ and NAHF $(4.30$ $\pm 0.15 \%)$. Milk density was significantly higher $\left(1.0313 \mathrm{~g} / \mathrm{cm}^{3} \pm 0.00026, P<0.05\right)$ for the milk of Jersey breed when compared to the EHF $\left(1.0304 \pm 0.00026 \mathrm{~g} / \mathrm{cm}^{3}\right)$ and NAHF $\left(1.0303 \pm 0.00024 \mathrm{~g} / \mathrm{cm}^{3}\right)$ genetic groups. The results from this study can be used by farmers and dairy processors alike to enhance accuracy when calculating the quantity and value of milk solids depending upon the genetic merit of the animal/herd, and may also improve milk payment systems through relating milk solids content and density.

Keywords

Composition • density • genetic group • raw milk • whole milk

\section{Introduction}

Composition is an important determinant of the processability and nutritive value of milk (Lindmark-Månsson et al., 2003) and also affects the quality of final products (Amenu \& Deeth, 2007). Differences in milk composition have been observed among different cow breeds and also in individual cows within the same breed, partially attributed to the genetic variations between cows (McLean et al., 1984; Tyrisevä et al., 2004; Wedholm et al., 2006; Gustavsson et al., 2014; Penasa et al., 2014; Bland et al., 2015; Stocco et al., 2017). Past experiments have shown that Jersey cows yield higher concentrations of fat and protein as compared to Friesian cows (Mackle et al., 1996; Auldist et al., 2004). These variances in fat and protein are attributed to differences in fatty acid and individual protein profiles within the milk and, according to literature, are influenced by breed (Peterson et al., 2002; Soyeurt et al., 2007; Bobe et al., 2008; Maurice-Van Eijndhoven et al., 2011, 2013). This correlation indicates that genetic selection for milk production affects the composition of milk protein and content of milk fatty acids (McLean et al., 1984; DePeters et al., 1995). Similar effects of breed on milk fat and fatty acid composition have also been reported for Irish milk (Lawless et al., 1999; Dillon et al., 2003; Walsh et al., 2008; O'Callaghan et al., 2016).

The density of milk is an important physical characteristic that is widely used for weight-volume calculations, product mix management and profitability calculations. The density 
of milk is used to convert the volume of milk entering a processing environment to weight/mass of milk. The weight of individual constitutents in milk can then be determined by multiplying the mass of milk entering the processing system by the constituents' percentage. There is a direct correlation between the content of fat and milk solids and milk density (Ueda, 1999). Milk density is correlated with the size of fat globules (Ueda, 1999) and fat globule size is dependent upon characteristics like feeding treatment, seasonal and compositional changes, breed, physiology of the animal and stage of lactation (Walstra, 1969; Walstra \& Mulder, 1974; Huhtanen \& Rinne, 2007; Heck et al., 2009; Kljajevic et al., 2018; Parmar et al., 2020). Breed and genetic characterisitics of the animal significantly affect the concentration and ratio of fatty acids in milk fat and affect the processability, i.e. its hardness or softness (MacGibbon, 1996). Processes such as homogenisation lead to smaller fat globules with a larger surface area, and also a higher density (Truong et al., 2016). It has been noted through past research that the content of fatty acids such as stearic, palmitic, and oleic acids is positively correlated with the size of milk fat globules (Wiking et al., 2004). Milk from different breeds of cows has varying fatty acid content, which affects the overall fat concentration and also affects the fat globule size (Marín et al., 2018). This has been attributed to the genetic merit and breed characteristics influencing the milk composition (White et al., 2001; Auldist et al., 2004; Larsen et al., 2012).

Breed variations also impact the protein content in milk as observed from various studies (Ng-Kwai-Hang et al., 1986; Malacarne et al., 2006; De Marchi et al., 2008). Malacarne et al. (2006) found that protein content $(3.49 \%)$ and subsequent cheese yield was markedly higher for Italian Brown cows compared to Friesian cows (3.07\%). A comparison of Danish Jersey, Swedish red and Danish Holstein cows also showed that there was a significant difference in concentration of protein in milk (Gustavsson et al., 2014). Individual protein concentration and overall content of protein are affected by the genetic variations and influence processing capabilities, including coagulation properties. However, milk density is largely dependent upon factors such as milk fat content, fat globule size and ratio of solid:liquid fat (Ueda, 1999).

Peak season for milk production and supply in Ireland is the period between March and May/June when milk production increases steadily, hitting a peak in May/June, plateauing in July-August and begins falling (off-peak) from the autumn/winter period (as grass growth begins to decline). This is evident from the data available for milk production and intake of creameries in Ireland for 2018 (CSO, 2018). While the effect of breed on milk composition has been well established through numerous research studies, the effect of genetic group on raw whole milk density has not been studied and is unavailable in the literature. The current study was designed to investigate the interaction between cow genetic group and milk density, measured through different analytical approaches, and observed for one complete season (March-November 2018), including peak and offpeak. The composition of milk samples obtained from different cow genetic groups was also measured and results were evaluated to determine the interaction between genetic group, density and analytical approach.

\section{Materials and methods}

\section{Experimental design and sampling}

The research was carried out over a period of 9 mo from March 2018 to November 2018. Season was defined as spring (March, April, May), summer (June, July, August) and autumn (September, October, November). Raw whole milk samples from the combined evening and morning milking were obtained from a Teagasc Research farm, Kilworth, Co. Cork (latitude $50^{\circ} 07^{\prime} \mathrm{N}$, longitude $\left.08^{\circ} 16^{\prime} \mathrm{W}\right)$. The genetic groups and breeds assessed in this study included Jersey, and two genetic groups of Holstein-Friesian breed, i.e. elite Holstein-Friesian (EHF) and national average genetic merit Holstein-Friesian (NAHF) cows. FHF and NAHF cows were chosen on the basis of the economic breeding index $(\mathrm{EBI})$. The $\mathrm{EBI}$ is a profit index aimed at providing information to farmers regarding the selection of cows for breeding herd replacements (Berry et al., 2005). All the cows $(n=54)$ included in the study were milked twice a day. The cows were segregated into three groups on the basis of feed (three different feed patterns explained below) given to each genetic group and six cows were selected for each feed pattern ( $6 \times 3=18$ cows per genetic group). Indicative feeding treatments were as follows:

(a) Control system: Stocking rate (SR) of 2.75 cows/ha, $250 \mathrm{~kg} \mathrm{~N} / \mathrm{ha}$. Concentrate (3 kg) was offered per cow per day immediately post calving to supplement pasture availability in the spring (12 wk). Pasture was allocated in accordance with best management practice in midseason (approx. $4.5 \mathrm{~cm}$ post grazing residual; $18 \mathrm{wk}$ ). A grass only diet was offered in the autumn period (12 wk). Post grazing residual was managed at $4.5 \mathrm{~cm}$ in the spring and autumn.

(b) High concentrate system: Concentrate $(7 \mathrm{~kg})$ was offered per cow per day immediately post calving to supplement pasture availability in the spring (12 wk). A $4 \mathrm{~kg} / \mathrm{cow}$ per day supplementation was offered in the autumn period (12 wk). Pasture allocation, stocking rate and post grazing residual was similar to the control.

(c) Lower grass residual: Concentrate (3 kg) was offered per cow per day immediately post calving to supplement pasture availability in the spring (12 wk). A grass only diet was offered in the autumn period (12 wk). Post grazing 
residual was $3.5-4 \mathrm{~cm}$ in the spring and autumn. Pasture allocation and stocking rate was similar to the control.

A total of 1,040 samples of approx. $150 \mathrm{~mL}$ each were collected during this period and each of the samples were tested for compositional profile and whole milk density. The following parameters were measured: fat, protein, total solids content, while raw milk density was evaluated using three different analytical approaches. The milk composition was determined using a Dairyspec FT manual model (Bentley Dairy Systems, Chaska, MN, USA) while the milk density was determined using three different analytical approaches - using a DMA 35 portable density meter (Anton Paar, Graz, Austria), a DMA 4500 desktop density meter (Anton Paar, Graz, Austria) and $100 \mathrm{~cm}^{3}$ calibrated glass pycnometers (Blaubrand, Wertheim, Germany). Sampling procedures were in accordance with ISO 707:2008 (Milk and Milk Products: Guidance on sampling) (ISO, 2008). The number of samples collected for each genetic group throughout is shown in Table 1.

Evening samples were collected and stored under refrigerated conditions at $5^{\circ} \mathrm{C}$ for $18 \mathrm{~h}$ to prevent microbial growth and enzymatic activities. Morning samples were collected the next day and mixed with the evening samples to prepare a representative sample. The samples were then tested for composition and density immediately after morning milk recording to prevent alteration to composition or spoilage. Therefore, the analysis was always completed within $24 \mathrm{~h}$ of the earliest milk collection.

\section{Methodology}

The raw milk density was determined using three different methods, i.e. a DMA35 portable density meter, a standard desktop density meter DMA4500 and the results from these two methods were then compared against the results obtained from measurements using $100 \mathrm{~cm}^{3}$ glass calibrated pycnometers. The samples collected were properly agitated before analysis to ensure thorough mixing of constituents and to remove any errors due to settling. Before analysis, the density meters were also calibrated using distilled water. Once calibrated, one sample at a time was analysed from start to finish on all three analytical methods, while maintaining sample temperature at approx. $20^{\circ} \mathrm{C}$. After completing density measurement for all samples, the samples were then analysed on the Dairyspec infrared manual (Fourier transform (FT) model for milk composition.

\section{DMA4500 and DMA35}

DMA35 is used as a method for density measurement across industry due to rapid results, easier handling and manoeuvrability. It works on the principle of hollow oscillating U-tube technology. The principle of operation in the two different pieces of equipment (DMA35 and DMA4500) is based on the principle of changing frequency of a hydrogen filled hollow oscillator when filled with different liquids. The mass and density of the liquid changes the natural frequency of the oscillator due to overall change in mass of the oscillator when a liquid is added into the tube. The DMA4500 is capable of evaluating density with precision of $0.00005 \mathrm{~g} / \mathrm{cm}^{3}$ and $0.02^{\circ} \mathrm{C}$ with a working temperature range of $0-100^{\circ} \mathrm{C}$ and requires only $1-2 \mathrm{~mL}$ of sample, requires no viscosity-related standards and eliminates temperature-related fluctuations. The DMA4500 can be calibrated at one temperature and all samples for density can be measured at the set temperature. The equipment is also capable of automated cleansing and introduces immediate temperature equilibrium. The measured density of water at $20^{\circ} \mathrm{C}$ using DMA 35 was $0.9974 \mathrm{~g} / \mathrm{cm}^{3}$ and, for DMA4500, it was noted to be $0.99826 \mathrm{~g} / \mathrm{cm}^{3}$, close to the theoretical value of $0.99820 \mathrm{~g} / \mathrm{cm}^{3}$ for water at $20^{\circ} \mathrm{C}$.

\section{AOAC standard method using glass pycnometers}

The third method used to measure density was the Association of Official Agricultural Chemists (AOAC) 925.22 official method for determining the specific gravity of a liquid using pycnometry. Calibrated $100-\mathrm{cm}^{3}$ glass density pycnometers (Make Blaubrand BR43338, Wertheim, Germany) were used to determine the density of the milk samples. The densities of liquids attained from pycnometry method are compared against water. In this method, firstly, the empty glass bottle was weighed and noted. The glass bottle was then filled with distilled water and wiped dry to remove any water on the outer surface of the bottle. This filled mass was then measured and noted, after which the bottle was emptied completely. The bottle was then filled with liquid (milk) and the outer surface was wiped dry and weighed again. Excess liquid or water from the bottle was removed from the bottle through a capillary action of the bottle lid. The density of the liquid against that of water was measured using the formula

$$
\text { Density }=\frac{W S-W E}{W W-W E}
$$

Where WS is the weight of a sample-filled bottle, WE is the weight of an empty bottle and WW is the weight of a waterfilled bottle.

The sample was firstly tested on the DMA35 with approx. 1-2 $\mathrm{mL}$ of sample drawn directly from the sample container and the density was noted from the display screen of the equipment. Secondly, $2 \mathrm{~mL}$ syringes were used to inject the samples into the oscillating tubes of the DMA4500 equipment, preventing the flow of air into the sample. The desktop model DMA4500 was adjusted to note the density of milk samples at 
$20^{\circ} \mathrm{C}$ for all samples using the temperature settings available on the panel. The milk density of samples was then noted using the glass bottles from the standard AOAC 905.22 method and formula. The same procedure was applied to measure the density of all the samples collected during every run (18 samples for each genetic group each month). The glass pycnometer method requires a minimum of $100 \mathrm{~cm}^{3}$ sample for density measurement and thus needs to account for insufficient milk produced and collected at the farm, spillage and/or wastage. The number of sample points for the pycnometry method in this study are therefore less (approx. 740), compared to the other two methods (approx. 1,040 for the other two approaches).

After analysis of density was completed, the milk compositional profile, i.e. milk fat, protein and total solids content, was assessed by infrared spectrophotometry. An approx. volume of $30 \mathrm{~mL}$ sample was required to be tested on the Dairyspec infrared manual FT model (Bentley Instruments Inc.) calibrated for raw whole milk compositional analysis. The Dairyspec machine is based on the FTIR (Fourier transform infra-red spectroscopy) principle.

\section{Statistical analysis}

All dependent variables were analysed using the statistical package SAS version 9.4 (SAS Institute Inc., Cary, NC, USA). Descriptive statistics were obtained using the means procedure. Least square means (LSMeans) and s.e. for factors affecting milk composition and density were obtained using the mixed procedure. The model for milk composition traits included the fixed effects of genetic group, feeding treatment, parity, days in milk with linear and quadratic effect as covariates, and random effects of cow and residual error. Milk density was analysed with the same mixed model as for milk composition with the addition of analytical method (DMA4500, DMA35 and glass pycnometers) as fixed effects. LSMeans were used for multiple mean comparisons using the Fisher's least significant difference test and was implemented in the option LSMEANS and significant differences were defined at $P<0.05$. Variance components for $\operatorname{cow}\left(\sigma_{\text {cow }}^{2}\right)$ and residual $\left(\sigma_{\mathrm{e}}^{2}\right)$ were used to estimate repeatability of the trait, calculated as rep $=\sigma_{\text {cow }}^{2} / \sigma_{\text {total }}^{2}$ where $\sigma_{\text {total }}^{2}=\sigma_{\text {cow }}^{2}+\sigma_{\mathrm{e}}^{2}$.

\section{Results}

Descriptive statistics for milk composition for all samples collected during the period of study were determined. The average fat, protein, lactose, total solids, casein and weighted average density values are presented in Table 1. The coefficient of variation was also determined for each of the constituents analysed and are shown in Table 1.
Table 1: Mean, SD, CV and minimum and maximum values of milk composition $(n=1,044)$ and density - samples $(n=2,836)$ collected from three cow genetic groups (averaged results)

\begin{tabular}{lccccc}
\hline Trait & Mean & SD & CV & Minimum & Maximum \\
\hline Fat, \% & 4.73 & 1.30 & 27 & 2.14 & 14.86 \\
Protein, \% & 3.85 & 0.56 & 16 & 1.76 & 5.95 \\
Total solids, \% & 14.03 & 2.21 & 19 & 8.57 & 22.48 \\
Casein, \% & 2.88 & 0.58 & 20 & 0.61 & 5.00 \\
Lactose, \% & 4.70 & 0.30 & 6 & 2.45 & 5.61 \\
Density, g/cm & 1.0308 & 0.002 & 0.20 & 1.0153 & 1.0378 \\
\hline
\end{tabular}

Table 2: LSMeans and s.e. of milk composition and density from three cow genetic groups

\begin{tabular}{|c|c|c|c|c|}
\hline Trait & Genetic group ${ }^{1}$ & $n$ & LSMean & SE \\
\hline \multirow[t]{3}{*}{ Fat, \% } & EHF & 357 & $4.81^{b}$ & 0.165 \\
\hline & Jersey & 341 & $5.69^{c}$ & 0.131 \\
\hline & NAHF & 346 & $4.30^{\mathrm{a}}$ & 0.154 \\
\hline \multirow[t]{3}{*}{ Protein, \% } & EHF & 357 & $3.82^{\mathrm{a}}$ & 0.063 \\
\hline & Jersey & 341 & $4.18^{b}$ & 0.050 \\
\hline & $\mathrm{NHF}$ & 346 & $3.73^{\mathrm{a}}$ & 0.058 \\
\hline \multirow[t]{3}{*}{ Total solids, \% } & EHF & 357 & $14.11^{\mathrm{b}}$ & 0.242 \\
\hline & Jersey & 341 & $15.36^{c}$ & 0.185 \\
\hline & NHF & 346 & $13.34^{\mathrm{a}}$ & 0.227 \\
\hline \multirow[t]{3}{*}{ Lactose, \% } & EHF & 357 & $4.63^{a}$ & 0.031 \\
\hline & Jersey & 341 & $4.67^{a}$ & 0.037 \\
\hline & NAHF & 346 & $4.61^{\mathrm{a}}$ & 0.026 \\
\hline \multirow[t]{3}{*}{ Casein, \% } & EHF & 357 & $2.89^{a}$ & 0.065 \\
\hline & Jersey & 341 & $3.15^{b}$ & 0.052 \\
\hline & NAHF & 346 & $2.82^{a}$ & 0.060 \\
\hline \multirow[t]{3}{*}{ Density, $\mathrm{g} / \mathrm{cm}^{3}$} & EHF & 330 & $1.0304^{a}$ & 0.00026 \\
\hline & Jersey & 301 & $1.0313^{\mathrm{b}}$ & 0.00021 \\
\hline & NAHF & 314 & $1.0303^{\mathrm{a}}$ & 0.00024 \\
\hline
\end{tabular}

${ }^{1}$ Elite HF = Elite Holstein-Friesian, NAHF = national average Holstein-Friesian.

a,b,cLSMeans with different superscript within each milk component are significantly different $(P<0.05)$. DMA 4500 method was used to measure density shown in this table. LSMeans, least square means.

Table 2 presents the LSMean values along with the s.e. for the constituents and density based on the genetic groups analysed. The fat content was highest and significantly different for Jersey cows, compared to FHF and NAHF cows $(P<0.05)$. The fat content for Jersey milk was approx. $30 \%$ higher compared to NAHF cow milk. Overall milk density LSMean value for Jersey milk was determined to be 
significantly higher $(P<0.05)$ from EHF and NAHF cows. The difference between density for Jersey cow milk and HolsteinFriesian cow milk was observed to be statistically significant $(P<0.05)$. Table 3 presents the density values for each of the genetic groups estimated with all three measurement techniques. The density values obtained for the pycnometer method were significantly different for all three genetic groups while density values obtained from DMA35 and DMA4500 methods (for all genetic groups) were not significantly different $(P>0.05)$. Table 4 presents the analysis for density when the same number of samples $(n)$ was used for estimation of density for all three measurement techniques.

The pycnometer method showed the highest estimate of density and pycnometer density results were significantly higher $(P<0.05)$ from those of the other two methods [DMA 35 and DMA4500, no significant difference between DMA 35 and DMA $4500(P>0.05)]$. Table 5 shows the Pearson's

Table 3: LSMeans and s.e. of genetic group-wise milk density determined by three analytical methods

\begin{tabular}{lccc}
\hline Genetic group & Method & LSMean & SE \\
\hline EHF & Pycnometer & $1.0319^{\mathrm{a}}$ & 0.00024 \\
& DMA35 & $1.0296^{\mathrm{b}}$ & 0.00024 \\
\multirow{3}{*}{ Jersey } & DMA4500 & $1.0296^{\mathrm{b}}$ & 0.00024 \\
& Pycnometer & $1.0327^{\mathrm{a}}$ & 0.00021 \\
& DMA35 & $1.0308^{\mathrm{b}}$ & 0.00021 \\
NAHF & DMA4500 & $1.0308^{\mathrm{b}}$ & 0.00021 \\
& Pycnometer & $1.0318^{\mathrm{a}}$ & 0.00023 \\
& DMA35 & $1.0295^{\mathrm{b}}$ & 0.00023 \\
& DMA4500 & $1.0296^{\mathrm{b}}$ & 0.00023 \\
\hline
\end{tabular}

EHF = Elite Holstein-Friesian, NAHF = national average HolsteinFriesian.

a,b LSMeans with different superscript within each genetic group are significantly different $(P<0.05)$. LSMeans, least square means.

Table 4: LSMeans, least square means. and s.e. of milk density determined by three analytical methods (to assess the effect of each measurement technique)

\begin{tabular}{lccc}
\hline Method $^{1}$ & N & LSMean & SE \\
\hline Pycnometer & 744 & $1.0321^{\mathrm{b}}$ & 0.0001 \\
DMA35 & 744 & $1.0300^{\mathrm{a}}$ & 0.0001 \\
DMA4500 & 744 & $1.0300^{\mathrm{a}}$ & 0.0001 \\
\hline
\end{tabular}

a,b LSMeans with different superscript are significantly different $(P<0.05)$.

${ }^{1}$ Analytical methods used for measurement of milk density, discussed in detail in Materials and methods. LSMeans, least square means.
Table 5: Pearson correlation coefficients determined to compare the relationship between the three measurement techniques pycnometer method as a gold standard; DMA35 and DMA4500 compared with the standard

\begin{tabular}{lcc}
\hline \multicolumn{3}{c}{ Pearson correlation coefficients } \\
\hline Pycnometer & DMA35 & DMA4500 \\
\hline 1.00 & 0.82 & 0.83 \\
& $<0.0001$ & $<0.0001$ \\
0.82 & 1.00 & 0.92 \\
$<0.0001$ & & $<0.0001$ \\
0.83 & 0.92 & 1.00 \\
$<0.0001$ & $<0.0001$ & \\
\hline
\end{tabular}

Table 6: Estimates of variance components and repeatability of milk density for three cow genetic groups

\begin{tabular}{lcccc}
\hline Trait & $\begin{array}{c}\text { Between } \\
\text { cows }\end{array}$ & $\begin{array}{c}\text { Within } \\
\text { cow }\end{array}$ & Total & Repeatability (\%) \\
\hline Fat & 0.24 & 0.69 & 0.93 & 26.22 \\
Protein & 0.04 & 0.08 & 0.12 & 30.26 \\
Density & $6.779 \mathrm{E}-7$ & $2.636 \mathrm{E}-6$ & $3.31 \mathrm{E}-6$ & 20.45 \\
\hline
\end{tabular}

correlation coefficient determining the relationships between the three methods. The pycnometer method was established as the gold standard and the other two methods were compared against it. Lastly, in Table 6, covariance parameters were determined to test the repeatability of the effect of the cow on density variation over the sampling period. Random cow effects on density accounted for $20.45 \%$ of between-cow effects and $79.54 \%$ for within-cow effects, which could be attributed to genetic merit and inter-genetic group differences.

\section{Discussion}

\section{Effect of genetic group on raw milk density}

The impact of breed on different characteristics of milk such as composition profile, fatty acid profile, processability, etc. has been well established in the literature (Malossini et al., 1996; Kelsey et al., 2003; Lock \& Bauman, 2004; Tyrisevä et al., 2004; Yang et al., 2013; Penasa et al., 2014; Bland et al., 2015; Stocco et al., 2017). However, the impact of breed and the use of different types of analytical approaches to measure raw milk density have not been widely addressed, to the best of our knowledge. The effect of genetic group on milk composition, for example, fat and protein levels, fatty acid composition and protein polymorphisms has been discussed widely (Ng-Kwai-Hang et al., 1986; Malacarne et al., 2006; 
De Marchi et al., 2008; Heck et al., 2009; Kljajevic et al., 2018). Because of genetic background and traits, milk samples collected from different cattle genetic groups have diverse compositional profile. A similar trend was observed in the results of this study, where fat, protein and total solids content varied across different genetic groups over the period of study. Sample-related factors include temperature history of the sample, inclusion of air and concentration of fat and solidsnon-fat. Other factors affecting physical characteristics and composition of milk may be the genetic merit of the cow, feeding treatment, lactation cycle and period and interand intra-herd variations (McLean et al., 1984; Wedholm et al., 2006; Huhtanen \& Rinne, 2007; Gustavsson et al., 2014). Sample-related factors such as temperature and temperature history of the sample have been described (Short, 1955; Hlaváč \& Božiková, 2011). The results for milk density from this study show the highest density value for Jersey milk, compared to EHF and NAHF cows. This may be attributed to genetic merit of the animal and variations in milk fat concentration due to genetic group effects.

Genetic merit and its impact on milk composition has been extensively studied in the literature. Milk fat is mainly present in globule form as an oil-in-water emulsion (MacGibbon, 1996) and fat is comprised of approx. 400 different types of fatty acids, out of which approx. $70 \%$ are saturated fatty acids and the remaining $30 \%$ are unsaturated. The fatty acid profile of milk is dependent upon different factors: animal breed, stage of lactation, feed, and microbial activity in the rumen of the animal. The main pre-cursors of milk fat, i.e. acetic and butyric fatty acids - derived from rumen fermentation, can be affected by diet through changes in rumen fermentation, directly dependent upon the genetic variations in cows. The impact of genetic variations and background significantly affects the fatty acid composition in individual breeds, for example, a higher content of short chain fatty acids and to some extent, medium chain fatty acids were observed in Danish Holstein cows compared to the Danish Jersey breed (Poulsen et al., 2012). It has been noted through past research that the content of fatty acids such as stearic, palmitic, and oleic acid is positively correlated to the size of milk fat globule (Wiking et al., 2004). Walstra \& Mulder (1974) suggested that the majority $(94 \%)$ of fat globules are sized between 2 and $8 \mu \mathrm{m}$ and the fat globule size is dependent upon characteristics like breed, physiology of the animal and lactation period. Milk fat globule size directly impacts the milk density and the size of globules increase with an increase in fat content of milk, due to limited membrane production (Wiking et al., 2004). However, the size of milk fat globule was not measured in this study but it is clear that the changes in milk fat globule size and subsequent milk density are directly correlated to the genetic merit of the animal, as shown from the results of this study (Table 2). This outcome was also corroborated by other studies available in literature (White et al., 2001; Larsen et al., 2012) and is independent of dietary effects on composition and only due to genetic traits and breed differences (Beaulieu \& Palmquist, 1995). Thus, the size of milk fat globules critically affects the stability, technological and physical properties of milk, such as density, and is reliant on characteristics like breed and physiology of cows (Heck et al., 2009; Kljajevic et al., 2018). Disintegration of fat globules during proccessing also impacts the size of milk globule and, therefore affects the milk density.

A related assessment of the effect of breed on protein profile and individual protein content was conducted by Gustavsson et al. (2014). The results from their study showed a significant impact of breed on the relative overall concentrations of proteins (as shown in the results of this study, milk of Jersey cows have highest protein content, compared to EHF and NAHF strains of Holstein Friesian). Protein content, as well as its composition, is known to impact the processability of milk (Malossini et al., 1996; Tyrisevä et al., 2004; Wedholm et al., 2006; Ketto et al., 2017; Poulsen et al., 2017), however, its impact on milk density is not clearly established. The impact of seasonal and compositional variation on milk density has been assessed in a study by the same authors (Parmar et al., 2020), which showed that variation in milk constituents including protein over different seasons significantly impacted milk density $(P<0.05)$.

Other studies in the literature have observed an inverse relationship between milk fat content and milk density values (Czerniewicz et al., 2006). However, Parmar et al. (2020) stated that fat content was the most important contributor to density value, other intrinsic (protein, lactose, genetic traits and parity) and extrinsic factors (days in milk, season, feeding treatment, and measurement technique) have statistically significant impacts on milk density.

\section{Effect of analytical technique on the measurement of raw milk density}

The results from this study indicate a significant impact of the measuring technique on the raw milk density for all the samples studied. The results were significantly affected by measurement method $(P<0.05)$ with $100 \mathrm{~cm}^{3}$ glass pycnometers recording the highest values of density for all genetic groups. The results of density measured from $100 \mathrm{~cm}^{3}$ glass pycnometers, as per the AOAC method, revealed a higher value of density as compared to the results of the DMA 35 and DMA 4500 with all samples undergoing the same treatment and also thoroughly mixed to mix constituents and to avoid any settlement issues (storage conditions). This may be attributed to the precision and tolerance limits of the measurement technique, along with variations in 
density introduced due to temperature history of the samples and Recknagel's phenomenon. Recknagel's phenomenon refers to the density of sample measured immediately after milking being lower compared to milk stored for longer periods of time especially at lower temperatures. This is observed due to the increase in hydration of protein at lower temperatures instead of the escape of air bubbles (IASRI, 2012). Another critical factor affecting density measurement using different equipment is the temperature history of the samples. The samples collected in the evening were stored in a refrigerator overnight at $5^{\circ} \mathrm{C}$ and were mixed with freshly collected samples from the morning milking. This affected the temperature of the representative sample subsequently used for density measurement. The temperature of measurement for the DMA 4500 was standardised at $20^{\circ} \mathrm{C}$ for all samples while temperature variations could have been introduced into density measurement when assessed on the DMA 35 and $100-\mathrm{cm}^{3}$ glass bottles. This may be attributed to the temperature sensitivity of the DMA 35 and no temperature control was used during the use of pycnometers for density measurement. Past research has highlighted the need to determine the controlled temperature history necessary for high precision and accurate density measurement (Sharp \& Hart, 1936; Vanstone, 1960; Hilker \& Caldwell, 1961). Other factors affecting the density measurement using bottles may include the possible presence of foreign particles in the sample, entrapped air, bubble formation, temperature influence and/or viscosity-related errors.

\section{Conclusions}

Genetic traits and merit of the animal significantly impacts on whole milk density, in conjunction with other factors like composition, feed treatment, seasonality, processing environment and temperature. To the best of our knowledge, this is the first of its kind of research, especially for the Irish dairy sector, wherein the breed of the animal has been studied to analyse its impact on milk density, which is an integral parameter in weight-volume calculations in a dairy processing environment. Milk density factors established for different genetic groups in this study may be helpful in estimating weight-volume relationships based on milk supplied from different herds (genetic groups). This will also help in calculating the weight of milk constituents received for processing. The relationship between genetic group and density, thus, established, may enable the inclusion of breed as a support parameter in decision-making for milk payments. Also, the determination of density using different analytical methods presents a new perspective and can influence density values as seen in this study. It was shown that genetic groups producing higher fat content of milk tended towards a higher density value which could be important decisionsupport information for the milk payment schemes.

\section{Acknowledgements}

This study was funded by Enterprise Ireland (EI) under its Dairy Processing Technology Centre (DPTC) grant no. TC20140016 as well as a research grant from the Science Foundation Ireland and the Department of Agriculture, Food and Marine on behalf of the Government of Ireland under the Grant 16/RC/3835 (VistaMilk). We would like to express our sincere gratitude to the staff and management at the Teagasc Research Farm, Kilworth for their support and assistance in sample collection.

\section{References}

Amenu, B. and Deeth, H. 2007. The impact of milk composition on cheddar cheese manufacture. Australian Journal of Dairy Technology 62: 171-180.

Auldist, M., Johnston, K., White, N., Fitzsimons, W. and Boland, M. 2004. A comparison of the composition, coagulation characteristics and cheesemaking capacity of milk from Friesian and Jersey dairy cows. Journal of Dairy Research 71: 51-57.

Beaulieu, A. and Palmquist, D. 1995. Differential effects of high fat diets on fatty acid composition in milk of Jersey and Holstein cows. Journal of Dairy Science 78: 1336-1344.

Berry, D., Shalloo, L., Cromie, A., Olori, V. and Amer, P. 2005. "Economic Breeding Index for Dairy Cattle in Ireland". Irish Cattle Breeding Federation, Bandon, Cork, Ireland.

Bland, J., Grandison, A. and Fagan, C. 2015. Effect of blending Jersey and Holstein-Friesian milk on Cheddar cheese processing, composition, and quality. Journal of Dairy Science 98: 1-8.

Bobe, J., Lindberg, G., Freeman, A. and Beitz, D. 2008. Short communication: estimates of genetic variation of milk fatty acids in US Holstein Cows. Journal of Dairy Science 91: 1209-1213.

CSO. 2018. Intake of Cows Milk by Creameries and Pasteurisers by Domestic or Import Source, Month and Statistic. Central Statistical Office, UK. Available online: https://data.gov.ie/ dataset/intake-of-cows-milk-by-creameries-and-pasteurisersby-month-domestic-or-import-source-and-statistic [Accessed 5 March 2018].

Czerniewicz, M., Kiełczewska, K. and Kruk, A. 2006. Comparison of some physicochemical properties of milk from Holstein-Friesian and Jersey cows. Polish Journal of Food and Nutrition Sciences 15 (Suppl. 1): 61-64.

De Marchi, M., Bittante, G., Dal Zotto, R., Dalvit, C. and Cassandro, M. 2008. Effect of Holstein Friesian and Brown Swiss breeds on quality of milk and cheese. Journal of Dairy Science 91: 4092-4102. 
DePeters, E., Medrano, J. and Reed, B. 1995. Fatty acid composition of milk fat from three breeds of dairy cattle. Canadian Journal of Animal Science 75: 267-269.

Dillon, P., Buckley, F., O'Connor, P., Hegarty, D. and Rath, M. 2003. A comparison of different dairy cow breeds on a seasonal grassbased system of milk production: 1. Milk production, live weight, body condition score and DM intake. Livestock Production Science 83: 21-33.

Gustavsson, F., Buitenhuis, A.J., Johansson, M., Bertelsen, H.P., Glantz, M., Poulsen, N.A., Månsson, H.L., Stålhammar, H., Larsen, L.B., Bendixen, C. and Paulsson, M. 2014. Effects of breed and casein genetic variants on protein profile in milk from Swedish Red, Danish Holstein, and Danish Jersey cows. Journal of Dairy Science 97: 3866-3877.

Heck, J.M.L., Van Valenberg, H.J.F., Dijkstra, J. and Van Hooijdonk, A.C.M. 2009. Seasonal variation in the Dutch bovine raw milk composition. Journal of Dairy Science 92: 4745-4755.

Hilker, L.D. and Caldwell, W.R. 1961. A method for calculating the weight per gallon of fluid dairy products. Journal of Dairy Science 44: 183-188.

Hlaváč, P. and Božiková, M. 2011. Effect of temperature on milk rheologic and thermophysical properties. Journal on Processing and Energy in Agriculture 15: 17-22.

Huhtanen, P. and Rinne, M. 2007. Effects of increasing the milk yield of dairy cows on milk composition. Journal of Animal and Feed Sciences 16: 42-58.

IASRI. 2012. Factor affecting Density and Specific Gravity of Milk. Available online: http://ecoursesonline.iasri.res.in/mod/page/view. php?id=4151 [Retrieved 22 November 2018].

ISO. 2008. ISO 707:2008(en) Milk and milk products - Guidance on sampling. ISO.

Kelsey, J.A., Corl, B.A., Collier, R.J. and Bauman, D.E. 2003. The effect of breed, parity, and stage of lactation on conjugated linoleic acid (CLA) in milk fat from dairy cows. Journal of Dairy Science 86: 2588-2597.

Ketto, I.A., Knutsen, T.M., Øyaas, J., Heringstad, B., Ådnøy, T., Devold, T.G. and Skeie, S.B. 2017. Effects of milk protein polymorphism and composition, casein micelle size and salt distribution on the milk coagulation properties in Norwegian Red cattle. International Dairy Journal 70: 55-64.

Kljajevic, N.V., Tomasevic, I.B., Miloradovic, Z.N., Nedeljkovic, A., Miocinovic, J.B. and Jovanovic, S.T. 2018. Seasonal variations of Saanen goat milk composition and the impact of climatic conditions. Journal of Food Science and Technology 55: 299-303.

Larsen, M.K., Hymøller, L., Brask-Pedersen, D.B. and Weisbjerg, M.R. 2012. Milk fatty acid composition and production performance of Danish Holstein and Danish Jersey cows fed different amounts of linseed and rapeseed. Journal of Dairy Science 95: 3569-3578.

Lawless, F., Stanton, C., L'escop, P., Devery, R., Dillon, P. and Murphy, J.J. 1999. Influence of breed on bovine milk cis-9, trans11-conjugated linoleic acid content. Livestock Production Science 62: $43-49$.
Lindmark-Månsson, H., Fondén, R. and Pettersson, H.E. 2003. Composition of Swedish dairy milk. International Dairy Journal 13: 409-425.

Lock, A.L. and Bauman, D.E. 2004. Modifying milk fat composition of dairy cows to enhance fatty acids beneficial to human health. Lipids 39: 1197-1206.

MacGibbon, A.K.H. 1996. Herd-to-herd variations in the properties of milkfat. Proceedings - New Zealand Society of Animal Production, New Zealand Society of Animal Prod Publ, pp. 224-227.

Mackle, T.R., Parr, C.R., Stakelum, G.K., Bryant, A.M. and MacMillan, K.L. 1996. Feed conversion efficiency, daily pasture intake, and milk production of primiparous Friesian and Jersey cows calved at two different liveweights. New Zealand Journal of Agricultural Research 39: 357-370.

Malacarne, M., Summer, A., Fossa, E., Formaggioni, P., Franceschi, P., Pecorari, M. and Mariani, P. 2006. Composition, coagulation properties and Parmigiano-Reggiano cheese yield of Italian Brown and Italian Friesian herd milks. Journal of Dairy Research 73: 171-177.

Malossini, F., Bovolenta, S., Piras, C., Dalla Rosa, M. and Ventura, W. 1996. Effect of diet and breed on milk composition and rennet coagulation properties. Paper presented at the Annales de zootechnie 45: 29-40.

Marín, M.P., Meléndez, P.G., Aranda, P. and Ríos, C. 2018. Conjugated linoleic acid content and fatty acids profile of milk from grazing dairy cows in southern Chile fed varying amounts of concentrate. Journal of Applied Animal Research 46: 150-154.

Maurice-Van Eijndhoven, M.H.T., Hiemstra, S.J. and Calus, M.P.L. 2011. Milk fat composition of 4 cattle breeds in the Netherlands. Journal of Dairy Science 94: 1021-1025.

Maurice-Van Eijndhoven, M.H.T., Soyeurt, H., Dehareng, F. and Calus, M.P.L. 2013. Validation of fatty acid predictions in milk using midinfrared spectrometry across cattle breeds. Animal 7: 348.

McLean, D.M., Graham, E.B., Ponzoni, R.W. and McKenzie, H.A 1984. Effects of milk protein genetic variants on milk yield and composition. Journal of Dairy Research 51: 531-546.

Ng-Kwai-Hang, K.F., Hayes, J.F., Moxley, J.E. and Monardes, H.G. 1986. Relationships between milk protein polymorphisms and major milk constituents in Holstein-Friesian cows. Journal of Dairy Science 69: 22-26.

O'Callaghan, T.F., Hennessy, D., McAuliffe, S., Kilcawley, K.N., O'Donovan, M., Dillon, P., Ross, R.P. and Stanton, C. 2016. Effect of pasture versus indoor feeding systems on raw milk composition and quality over an entire lactation. Journal of Dairy Science 99: 9424-9440.

Parmar, P., Lopez-Villalobos, N., Tobin, J.T., Murphy, E., McDonagh, A., Crowley, S.V., Kelly, A.L. and Shalloo, L. 2020. The effect of compositional changes due to seasonal variation on milk density and the determination of season-based density conversion factors for use in the dairy industry. Foods 9: 1004.

Penasa, M., Tiezzi, F., Sturaro, A., Cassandro, M. and De Marchi, M. 2014. A comparison of the predicted coagulation characteristics 
and composition of milk from multi-breed herds of HolsteinFriesian, Brown Swiss and Simmental cows. International Dairy Journal 35: 6-10.

Peterson, D.G., Kelsey, J.A. and Bauman, D.E. 2002. Analysis of variation in cis-9, trans-11 conjugated linoleic acid (CLA) in milk fat of dairy cows. Journal of Dairy Science 85: 2164-2172.

Poulsen, N.A., Glantz, M., Rosengaard, A.K., Paulsson, M. and Larsen, L.B. 2017. Comparison of milk protein composition and rennet coagulation properties in native Swedish dairy cow breeds and high-yielding Swedish Red cows. Journal of Dairy Science 100: 8722-8734.

Poulsen, N.A., Gustavsson, F., Glantz, M., Paulsson, M., Larsen, L.B. and Larsen, M.K. 2012. The influence of feed and herd on fatty acid composition in 3 dairy breeds (Danish Holstein, Danish Jersey, and Swedish Red). Journal of Dairy Science 95: 6362-6371.

Sharp, P.F. and Hart, R.G. 1936. The influence of the physical state of the fat on the calculation of solids from the specific gravity of milk. Journal of Dairy Science 19: 683-695.

Short, A.L. 1955. 573. The temperature coefficient of expansion of raw milk. Journal of Dairy Research 22: 69-73.

Soyeurt, H., Gillon, A., Vanderick, S., Mayeres, P., Bertozzi, C. and Gengler, N. 2007. Estimation of heritability and genetic correlations for the major fatty acids in bovine milk. Journal of Dairy Science 90: 4435-4442.

Stocco, G., Cipolat-Gotet, C., Bobbo, T., Cecchinato, A. and Bittante, G. 2017. Breed of cow and herd productivity affect milk composition and modeling of coagulation, curd firming, and syneresis. Journal of Dairy Science 100: 129-145.

Truong, T., Palmer, M., Bansal, N. and Bhandari, B. 2016. In: "Effect of Milk Fat Globule Size on the Physical Functionality of Dairy Products" (eds. T. Truong, M. Palmer, N. Bansal and B. Bhandari), Springer Cham, Switzerland, pages 47-67.

Tyrisevä, A.M., Vahlsten, T., Ruottinen, O. and Ojala, M. 2004. Noncoagulation of milk in Finnish Ayrshire and Holstein-Friesian cows and effect of herds on milk coagulation ability. Journal of Dairy Science 87: 3958-3966.

Ueda, A. 1999. Relationship among milk density, composition, and temperature. A Thesis Presented to The Faculty of Graduate Studies of The University of Guelph.

Vanstone, E.D. 1960. "Prïnciples of Dairy Science". Cleaver-Hume Press Ltd, London, 238 pages.

Walsh, S., Buckley, F., Pierce, K., Byrne, N., Patton, J. and Dillon, P. 2008. Effects of breed and feeding system on milk production, body weight, body condition score, reproductive performance, and postpartum ovarian function. Journal of Dairy Science 91: 4401-4413.

Walstra, P. 1969. Studies on milk fat dispersion. 2. Globule-size distribution of cows milk. Netherlands Milk and Dairy JournalNederlands-Nederlands Melk En Zuiveltijdschrift 23: 99-110.

Walstra, P. and Mulder, H. 1974. "The Milk Fat Globule: Emulsion Science as Applied to Milk Products and Comparable Foods". Centre for Agricultural Publishing and Documentation, Wageningen, The Netherlands, 300 pages.

Wedholm, A., Hallén, E., Bach Larsen, L., Lindmark-Månsson, H., Hans Karlsson, A. and Allmere, T. 2006. Comparison of milk protein composition in a Swedish and a Danish dairy herd using reversed phase HPLC. Acta Agriculturae Scand Section A 56: 8-15.

White, S.L., Bertrand, J.A., Wade, M.R., Washburn, S.P., Green Jr, J.T. and Jenkins, T.C. 2001. Comparison of fatty acid content of milk from Jersey and Holstein cows consuming pasture or a total mixed ration. Journal of Dairy Science 84: 2295-2301.

Wiking, L., Stagsted, J., Björck, L. and Nielsen, J.H. 2004. Milk fat globule size is affected by fat production in dairy cows. International Dairy Journal 14: 909-913.

Yang, T.X., Li, H., Wang, F., Liu, X.L. and Li, Q.Y. 2013. Effect of cattle breeds on milk composition and technological characteristics in China. Asian-Australasian Journal of Animal Sciences 26: 896. 